\title{
On the Estimation of Energy Exchange between the Japan Sea and the Atmosphere during Winter Based upon the Energy Budget of Both the Atmosphere and the Sea*
}

\author{
By S. Manabe \\ Geophysical Institute, Division of Meteorology, Tokyo University
}

(Manuscript received 3 June, 1958)

\begin{abstract}
First, the amount of both sensible and latent energy exchange between the Japan Sea and the atmosphere during winter were computed based upon the balance requirement of energy in the atmosphere.

The detailed explanations about the method adopted here were made in the preceding paper about the modification of airmass over the Japan Sea during the period of typical outburst of cold continental air (12).

The mean amount of supplied heat during January and February 1955 thus obtained is as much as $555 \mathrm{cal} / \mathrm{cm}^{2} /$ day, though it is considerably smaller than that during the period of typical outburst of cold air at the end of December $1954\left(1030 \mathrm{cal} / \mathrm{cm}^{2} / \mathrm{day}\right)$.

On the other hand, the mean amount of evaporation during winter is about $5.6 \mathrm{~mm} / \mathrm{day}$ which corresponds to $340 \mathrm{cal} / \mathrm{cm}^{2} /$ day, and is considerably smaller than that of sensible heat, though the Bowen's ratio (6) is nearly equal to unity over the Japan Sea during this season.

Finally in order to verify these results, the amount of energy exchange was estimated based upon the balance requirement of the energy of sea water.
\end{abstract}

\section{Introduction}

In the preceding paper about the airmass modification over the Japan Sea (12), the present author analysed the situation during the period of the typical outburst of cold air from the Eurasian Continent by use of the network of both surface and upper air observations surrounding the Sea, and obtained the great deal of heat exchange $\left(1030 \mathrm{cal} / \mathrm{cm}^{2} /\right.$ day $)$ between sea and atomosphere. If this estimation is correct, in this area the amount of heat supplied from the sea to the atomosphere during the outburst period may be sufficient for altering the large scale temperature field or pressure pattern significantly in one or two days comparable with the forecast period of of numerical weather prediction at the present stage. As for the amount of supply of water vapor, same kind of discussion is applicable and this was expected to have most important effect on the amount of snowfall on the northwest coast of Japanese islands. Furthermore, in order to obtain some clue for the longer * Division of Meteorology, Contribution No.115. sumption, they obtained the ratio at which range forcasting, it seems to be necessary to estimate the amount of both sensible heat and latent heat exchange throughout winter and to obtain the climatological standard of airmasss modification over the Japan Sea during this season.

The climatological study about the energy supply from the sea by use of the data of both in the sea and in the atmosphere was already made by Jacobs (10). He computed the worldwide distribution of the exchange of heat and the water vapor for various seasons by use of his equations which were made based upon the energy budget of sea water. As for the energy budget of the Japan Sea itself, Miyazaki (13) performed the detailed investigation along the line proposed by Jocobs. Therefore direct comparison of his results for winter with ours will be made in this paper for the reasonable evaluation of both results.

In their estimations, Jabobs (10) and Miyazaki (13) assumed that the eddy conductivity of heat is equal to the eddy diffusivity of water vapor near the surface. Using this as- 
sensible and latent heat are supplied from the sea to the atomosphere, and which is known as Bowen's ratio (6). Over the Japan Sea, during the outburst period, this ratio was nearly equal to unity. However, according to our results in the preceding paper, supplied sensible heat seems to be twice as much as supplied latent heat, and to suggest the existence of intense convection over the sea surface besides trubulent mixing. Then, in this paper, it will be testified whether same tendency appears or not throughout winter.

These are the main theme for our present investigation. As the Japan Sea during winter season gives us the typical example of unstable situation, investigation of this sea from various standpoints may be effective for understanding the mechanism of the energy exchange between the sea and the unstable atomosphere.

\section{Brief explanation about the method of estimation*}

Since the Japan Sea is surrounded by the comparatively dense network of both surface and upper air observation stations, it is possible to get the fairly accurate values of net divergences of both enthalpy and water vapor by the line integral of the normal components of these fluxes along the boundary of the sea. On the other hand, the line integral of the components of observed wind vectors normal to the boundary gives us the mean divergence of air and accordingly the mean vertical velocity over the sea from which the mean vertical transport of various quantity is to be computed. Combining these two results, we estimated the degree of heating and the increment of water vapor content at various layers of the atmosphere during winter and obtained the total amounts by integrating these quantities with respect to pressure.

The equation which is used for the above computation is

$$
\begin{aligned}
& \int_{P_{0}}^{P_{1}}\left(\int^{J . S .} \frac{\overline{d Q}^{t_{0}}}{d t} d S\right) d p \\
\risingdotseq & C_{P} \int_{P_{0}}^{P_{1}}\left\{\int^{J . S .} \overline{\left(\frac{\partial T}{\partial t}+V_{g} \cdot \nabla T+\frac{T}{\theta} \omega \theta_{P}\right)^{t_{0}}} d S\right\} d p
\end{aligned}
$$

* Refer prededing paper (12) for the detailed explanations about our method and the observation network used.

$$
\begin{aligned}
= & C_{P} \int_{P^{0}}^{P_{1}}\left\{\frac{1}{t_{0}} \int^{J . s .}\left(T_{\text {final }}-T_{\text {initial }}\right) d S+\right. \\
& +\frac{1}{N} \sum_{i=1}^{N}\left(\oint^{J . S .} v_{g n} T d s\right)_{i} \\
& \left.+\overline{\bar{T}}^{\text {J.S. }}{ }^{t_{0}} \int^{\text {J.S. }} \overline{\omega \theta_{P}}{ }^{t_{0}} d S\right\} d p
\end{aligned}
$$

where $d Q / d t$ is the heat added to the unit gram of air during unit time interval, $\theta$ is potential temperature, $C_{p}$ is the specific heat under constant pressure, $T$ is the absolute temperature, $\omega$ is vertical $p$-velocity, $p_{0}$ and $p_{1}$ are the pressures at the surface and that at the highest level of the modified air mass respectively, J.S. indicates the Japan Sea, $t_{0}$ is the period treated, - $-J . S$. and $-t_{0}$ show the averaging process over the Japan Sea and dring the time interval $t_{0}$ respectively, $\boldsymbol{V}_{\boldsymbol{g}}$ is geostrophic wind vector, $d s$ and $d S$ are the line element along the boundary and the area element over the Japan Sea respectively, and $N$ is the number of observation during the time interval $t_{0}$.

For water vapor, the following equation, almost similar to (1) is available,

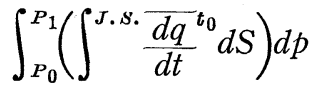

$$
\begin{aligned}
& \risingdotseq \int_{P_{0}}^{P_{0}}\left\{\int^{J . s .} \overline{\left(\frac{\partial q}{\partial t}+\boldsymbol{V}_{g} \cdot \nabla q+\omega q_{p}\right)^{t_{0}}} d S\right\} d p \\
& =\int_{P_{0}}^{P_{1}}\left\{\frac{1}{t_{0}} \int^{J . S .}\left(q_{\mathrm{final}}-q_{\text {initial }}\right) d S\right. \\
& \left.+\frac{1}{N} \sum_{i=1}^{N}\left(\oint^{\text {s.s. }} v_{g n} q d s\right)_{i}+\int^{J . s .} \overline{\omega q_{p}} t_{0} d S\right\} d p
\end{aligned}
$$

where $q$ is the mixing ratio i.e., mass in gram of water vapor per kilogram of dry air.

As is expressed in equations (1) and (2) for the computation of horizontal divergence of the temperature and the water vapor, geostrophic approximation was adopted at each standard level except the surface where half of the geostrophic divergence was used.

Concerning the vertical transport terms, following approximation was adopted i.e.,

$$
\begin{aligned}
& \overline{\overline{\bar{T}}^{J . S .}{ }^{t_{0}}} \int{\overline{\omega \theta_{P}}}^{t_{0}} d S \risingdotseq \\
& -\overline{\bar{T}^{J . S . t_{0}}{\overline{(\overline{l n} \theta)_{P}}}^{\text {J.S. }} t_{0}} \int_{P_{0}}^{P}\left\{\frac{1}{N} \sum_{i=1}^{N}\left(\oint^{J . s .} v_{n} d s\right)_{i}\right\} d p
\end{aligned}
$$




$$
\begin{aligned}
& \int^{J . S .} \overline{\omega q_{P} t_{0}} d S \doteqdot \\
& \quad-\overline{q_{P}^{J . S .} t_{0}} \int_{P_{0}}^{F}\left\{\frac{1}{N} \sum_{i=1}^{N}\left(\oint^{J . s .} v_{n} d s\right)_{i}\right\} d p
\end{aligned}
$$

At $500 \mathrm{mb}$ level, airmass modification due to the vertical eddy transport was assumed to be negligible based on the information about the height of inversion base.

On the other hand, the heating and cooling of air on the Japan Sea due to incoming solar radiation and long wave radiation were calculated by interpolating the values for the surrounding radiosonde observation stations, and the heat released by condensation is also estimated by use of the precipitation data of islands and coastal regions (refer preceding paper (12) for more detailed explanations).

The observation network used for these computation is almost same with the one adopted in the preceding paper (12). The only modification is made in the selection of wind data which were used for the estimation of surface divergence. The observation stations adopted for this purpose are Suttu, Akita, Niigata, Hekurajima, Wajima, Tottori, Yonago, Hagi, Fukuoka, Pusan and Kimpo (Block 47), and Kraskino, Pfusung, Tetuikhe and Terny (Block 31). As reference, those adopted for the computation of upper air divergence are Sapporo, Akita, Wajima, Yonago, Itazuke, Kimpo, Vladivostok and Terny.

Finally, from the balance requirement of heat energy and water vapor, estimation of the amounts of both quantities supplied from the sea to the atmosphere was performed.

Before discussing the results of these computation, it is necessary to estimate the magnitude of the systematic errors caused by the effects which were neglected in the above estimation.

First, discussion will be made

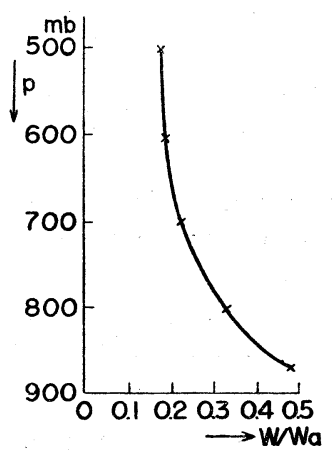

a

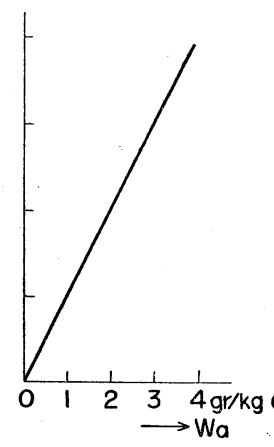

b this, the streamlines which have a cyclonic curvature predominate over the Japan Sea (refer Fig. 4b). Therefore, the geostrophic approximation which we adopted here has the tendency of over-estimation of the wind velocity. For the mean streamline during winter which passed over the middle part of the Japan Sea at $850 \mathrm{mb}$ level, the degree of overestimation caused by geostrophic approximation was roughly estimated to be about $13 \% *$. Therefore, we must keep in mind that the magnitude of horizontal divergences of both enthalpy and water vapor computed by use of geostrophic approximation is apt to be overestimated to this degree over the Japan Sea during winter due to the effect of cyclonic curvature of streamline.

Next, the discussion was made about the amount of liquid water content in the cloud. During winter, cumuli-form clonds usually develop over the northwest coast of Japanese islands i.e., over the outgoing side of the airmass from the Japan Sea, and hardly develop over the incoming side of it, so the neglection of liquid water content in the clouds may cause the under-estimation of divergence of total water. Concerning this problem, Warner a. Mean vertical distribution of $W / W_{a}$ in cumuliform cloud (after Warner (19)).

b. Mean vertical distribution of $W_{a}$ over the north-west coast of Japan during winter.

c. Mean vertical distribution of liquid water content. continuous line: $W \mathrm{gr} / \mathrm{kg}$ of air in the cloud. dotted line: $\quad W \mathrm{gr} / \mathrm{kg}$ of air of mean cloudiness. about the magnitude of the error caused by geostrophic approximation. During the winter, remarkable low center usually persists over the Okhotsok Sea. Corresponding to 
(19) measured the liquid water contents $W$ in many cumuliform clouds and found that it is always much less than the adiabatic value $W_{a}$. The mean ratio $W / W_{a}$ versus height from the cloud base which he obtained is shown in Fig. 1a. Using this ratio and assuming that the mean cloudiness is $70 \%$ at the cloud base and decreases to $0 \%$ linearly to $500 \mathrm{mb}$ level over the northwest coast of Japanese islands, we estimated approximately the magnitude of the liquid water content in the air of mean cloudiness which is shown in Fig. 1c (dotted line). Its mean value in the cloudy layer is about $0.125 \mathrm{gr} / \mathrm{kg}$ of air and is about $14 \%$ of the mean difference between the mixing ratio of water vapor at the outgoing side and that at the incoming side of the airmass where the clouds hardly exists. Then roughly speaking, the magnitude of the error of the computation of the horizontal divergence of water vapor is about $14 \%$ in the cloudy layer. Under $900 \mathrm{mb}$ level, i.e., in the subcloud layer, we need not worry about this error. Finally it may be said that the underestimation caused by the neglection of water content seems to be at most $14 \% *$.

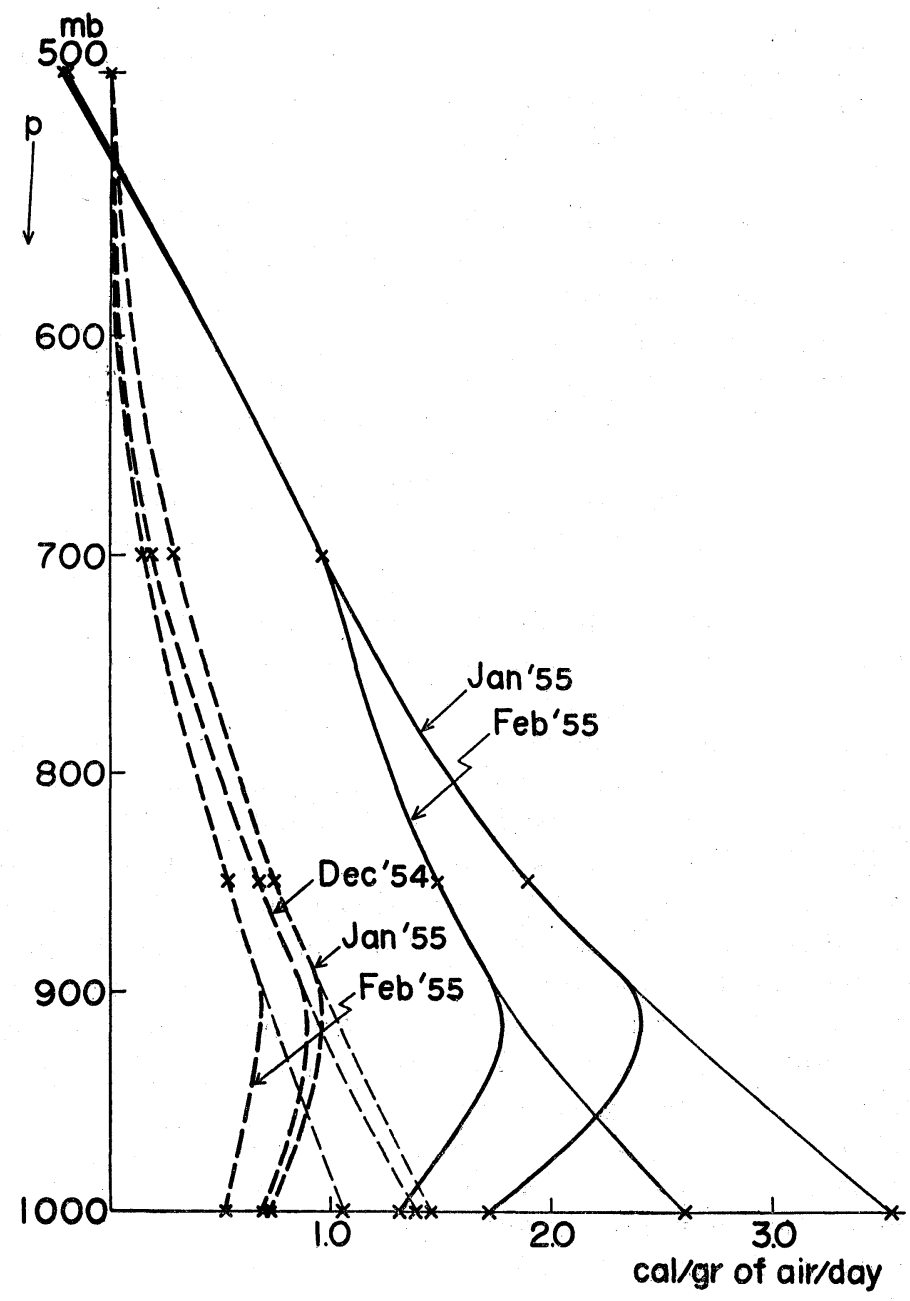

Fig. 2. Mean vertical distribution of the degree of air mass modification over the Japan Sea (Dec. 1954-Feb. 1955). continuous lines: Mean vertical distribution of heat added to the individual airmass (cal/gr of air/day).

dotted lines: Mean vertical distribution of the latent heat added to the individual air mass (cal/gr of air/day.)
Besides them, there are errors of the measurement of various quantities i.e., relative humidity, wind velocity and temperature. However, we omit the discussion of them, because they may be smaller than the errors which were discussed above. Concerning them, refer the paper after Hutchings about the moisture balance over England (9).

* Strictly speaking, as the temperature of cloud layer is usually lower than $0^{\circ} \mathrm{C}$ during winter, we must also consider about the ice content in the cloud. However, so far as the present author knows, there have not yet been such measurement unfortunately.

\section{Results of computations}

The periods for which the present analysis were applied are 2-31 December 1954, 1-28 January, and 1-26 February 1955**.

As for the general features of the situation over the Japan Sea, we described it in detail in the former paper selecting the typical outburst period, so in this paper we would not repeat it.

** When the remarkable cyclone passed over the Japan Sea at the beginning or at the end of each month, the days of passage were excluded from our analysis. 
Using the method explained briefly in the foregoing section, both the vertical distributions of the individual increasing rates of mixing ratio of water vapor and of the adding rate of heat energy were estimated and are shown in Fig. 2. Integrating these individual changes with respect to pressure, the degree of air mass modification was obtained for each month. On the other hand, net cooling due to radiation and heating due to condensation were estimated. As reference, the distribution of the mean daily precipitation over the Japan Sea during winter are shown in Fig. 3. Finally, from the balance requirement, the energy exchange at the air-sea boundary was estimated, which are tabulated in Table $1 .^{*}$ In the same table, the budget for the typical outburst period obtained in the preceding paper (12) is also shown as reference.

It is to be noted here that the degree of airmass modification during winter is considerably smaller than that during the typical outburst period, and this tendency is more remarkable for internal energy than for water vapor content. The amounts of heating due to condensation and of net cooling due to radiation during winter over the Japan Sea are considerably smaller than the energy supply from the sea surface similarly to the typical outburst period (12).

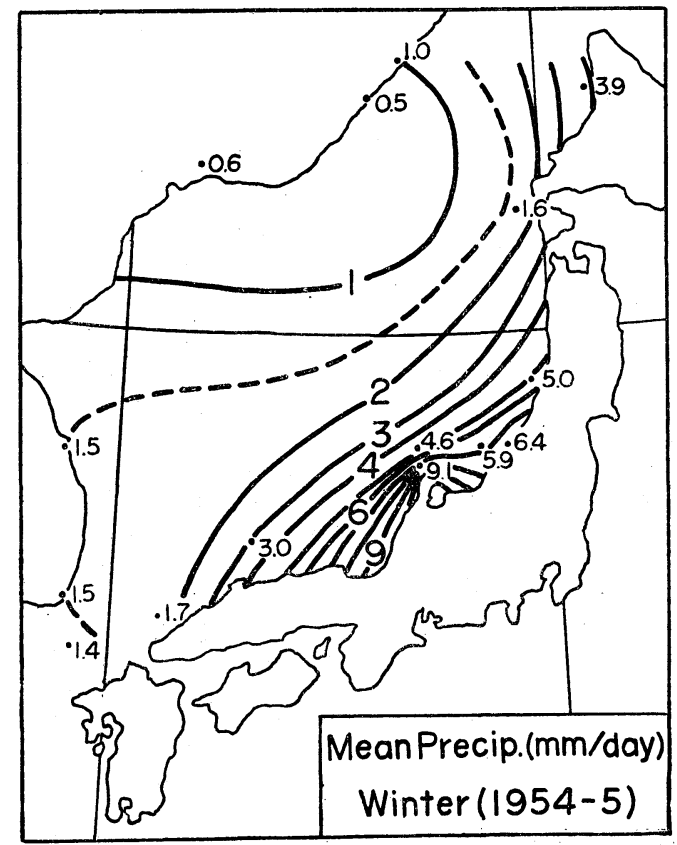

Fig. 3. Mean distribution of the amount of rainfall on the Japan Sea in mm/day (Dec. ' $54 \sim$ Feb. '55).

For the above computations, the vertical distribution of mean vertical current must be known (refer equations (1) and (2)). Here, the brief explanation of the distribution of this quantity seems to be necessary. In Fig. $4 \mathrm{a}$, the vertical distributions of monthly mean

Table 1. Energy Budget of the atmosphere over the Japan Sea during winter in the lower half of the atmosphere. (500 mb-surf.)

\begin{tabular}{|c|c|c|c|c|c|}
\hline & \multicolumn{4}{|c|}{ Winter } & \multirow{2}{*}{$\frac{\text { Outburst }}{\text { 20 Dec. '54-3 Jan. '55 }}$} \\
\hline . & 2-31 Dec. '54 & 1-28 Jan. '55 & 1-26 Feb. '55 & Average & \\
\hline$Q_{c}\left(\mathrm{cal} / \mathrm{cm}^{2} / \mathrm{day}\right)$ & \multirow{4}{*}{363} & 666 & 510 & 555 & 1030 \\
\hline$Q_{e}\left(\mathrm{cal} / \mathrm{cm}^{2} / \mathrm{day}\right)$ & & 337 & 319 & 340 & 450 \\
\hline$Q_{a}\left(\mathrm{cal} / \mathrm{cm}^{2} / \mathrm{day}\right)$ & & 943 & 829 & 895 & 1480 \\
\hline Rad. (cal/cm²/day) & & -87 & -78 & -83 & -93 \\
\hline Evap. (mm/day) & 6.0 & 5.6 & 5.3 & 5.6 & 7.5 \\
\hline Precip. (mm/day) & 2.5 & 1.7 & 1.7 & 2.0 & 1.3 \\
\hline
\end{tabular}

* Unfortunately, we could not help omitting the amount of the supply of sensible heat during December 1954 from the table, because the vertical distribution of supplied sensible heat is more irregular than those of other months. This irregularity chiefly came from the term of vertical transport of entropy in equation (1). divergence, which were computed by use of both surface and upper wind observations, are shown. The distributions have nearly the same tendency during the winter except the beginning of December 1954. The remarkable feature is the predominance of convergence at about $850 \mathrm{mb}$ level. As the mean 


\section{Mean divergence}

Dec.54-Feb.55
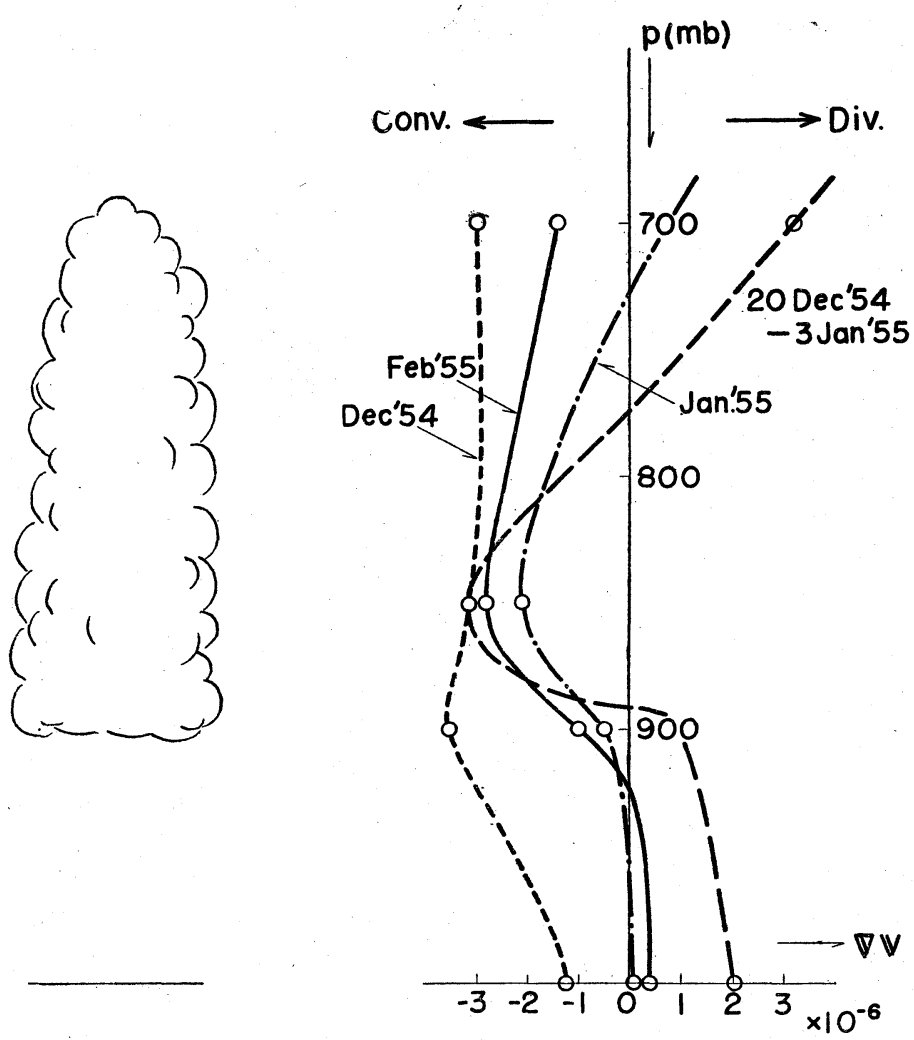

trough at $700 \mathrm{mb}$ level exists over the eastern part of the Japan Sea or over the Japanese islands during this period (refer Fig. 4b for example), it may be natural to expect the divergence in the lower half of the atmosphere. However, in this case the convergence appears at about $850 \mathrm{mb}$ level and the surface divergence is very weak. This layer of convergence roughly corresponds to the lower half of cloudy layer over the northwest coast of Japanese islands, so this might suggest that the cumulus convection caused by the heating from the sea surface affects the mean convergence. Further discussion of this phenomenon is impossible at the present stage of our investigation.

\section{Energy budget of the Japan Sea}

As the next step of our investigation, it is necessary to study the energy budget of the

Fig. 4a. Vertical distribution of mean divergence over the Japan Sea during winter.

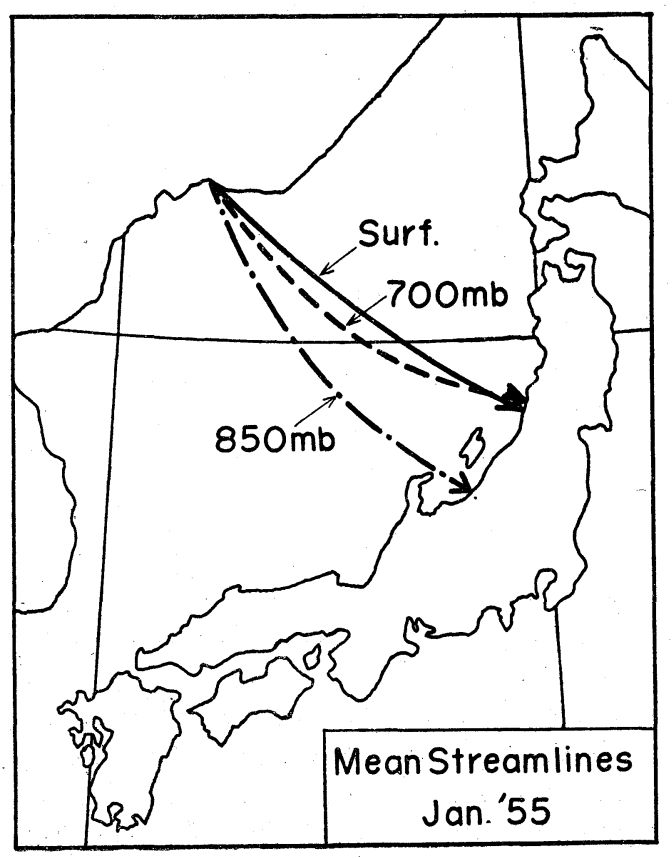

Japan Sea for the construction of the general picture of the energy exchange as well as for the verification of the results in the foregoing sections.

In 1949, Miyazaki (13) has already made the detailed investigation about this problem along the line proposed by Jacobs (10), and obtained the amount of energy exchange between the Japan Sea and the atmosphere for every seasons. Before comparing our results with those obtained by Miyazaki, his method will be explained briefly here.

The equation for the balance requirement of energy in the sea is

$$
Q_{a b}-Q_{b}-Q_{c}-Q_{e}+Q_{v}-Q_{d}=0
$$

where $Q_{a b}$ is the total heat absorbed at the surface, $Q_{b}$ is the total back radiation, $Q_{c}$ and $Q_{e}$ are the amounts of sensible and latent

Fig. 4b. Mean streamlines at various levels during winter passing through Vladivostok. 
energy exchange between sea and atmosphere through convection, $Q_{v}$ is the amount of heat added to the water mass through advective process and $Q_{d}$ is the change of internal energy of the sea water.

On the other hand, according to Mcntgomery (15), the amount of evaporation $E$ can be expressed by the following formula,

$$
E=K V_{a}\left(q_{s}-q_{a}\right)
$$

where $K$ is a constant, $V_{a}$ is the wind speed at ship-deck level, and $q_{s}$ and $q_{a}$ are the saturated mixing ratio of water vapor on the sea surface $(0.98$ times saturated mixing ratio over the pure water) and the mixing ratio at the ship-deck level respectively. Furthermore, if we assume that the eddy conductivity of heat is equal to the eddy diffusivity of water vapor, the following formula for the exchange of sensible heat is also obtained

$$
Q_{c}=C_{p} K V_{a}\left(T_{s}-T_{a}\right)
$$

where $T_{s}$ and $T_{a}$ are the sea surface temperature and the air temperature at ship-deck level respectively. Then the amount of total energy exchange $Q_{a}$ is

$$
Q_{a}=Q_{c}+Q_{e}=K V_{a}\left\{C_{p}\left(T_{s}-T_{a}\right)+L\left(q_{s}-q_{a}\right)\right\}
$$

From equation (5) and (8), $K$ may be expressed as follows,

$$
K=\frac{Q_{a b}-Q_{b}+Q_{v}-Q_{a}}{V_{a}\left\{C_{p}\left(T_{s}-T_{a}\right)+L\left(q_{s}-q_{a}\right)\right\}}
$$

The annual mean value of $K$ over the Japan Sea is

$$
\bar{K}=\frac{\int^{\text {Year }}\left\{\int^{J . S .}\left(Q_{a b}-Q_{b}\right) d S+Q_{v}\right\} d t}{\int^{J . S .}\left[\int^{\text {Year }} V_{a}\left\{C_{p}\left(T_{s}-T_{a}\right)+L\left(q_{s}-q_{a}\right)\right\} d t\right] d S}
$$

where the relation $\int_{Q_{a}}^{\text {Year }} d t=0$ was used. Based upon the data of 5 years $(1935-1940)$, Miyazaki (13) determined this value $\bar{K}$, and inserting this into equation (6) and (7), he obtained the distribution of $Q_{c}, E$, and $Q_{a}$ over the Japan Sea. Table 2 gives us the mean value of $Q_{a b}{ }^{*}, Q_{b}{ }^{*}$ and $Q_{v}{ }^{*}$ for

* As for the method of computation of $Q_{a b}, Q_{b}$ and $Q_{v}$, refer the papers after Jacobs (10) and Miyazaki (13). For the computation of $Q_{v}$, geostrophic approximation was used.

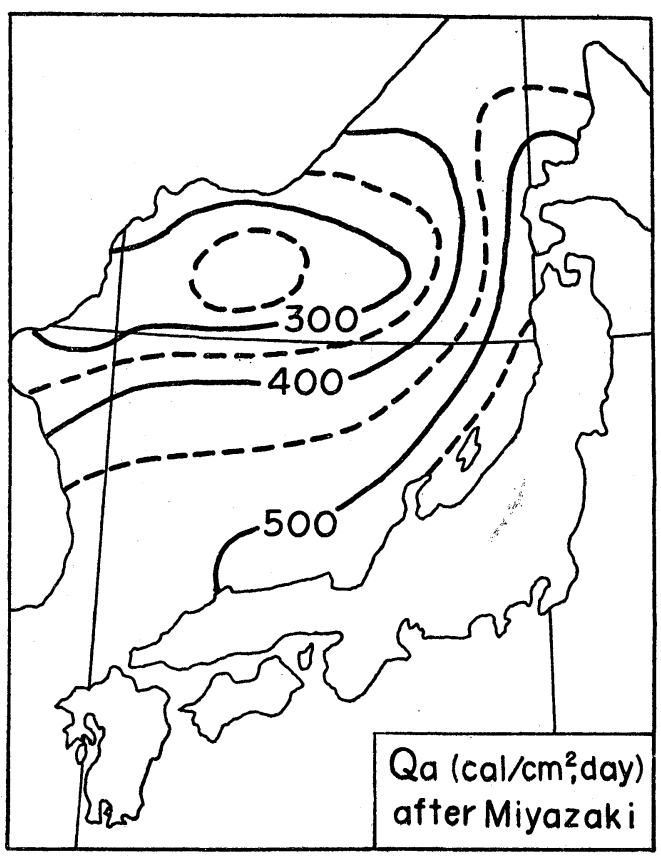

Fig. 5. Distribution of $Q_{a}\left(\mathrm{cal} / \mathrm{cm}^{2} /\right.$ day) over the Japan Sea during winter (after Miyazaki).

Table 2. Energy Budget of the Japan Sea during winter after Miyazaki.

\begin{tabular}{c|c|c|c|c|c}
\hline$Q_{a b}$ & $Q_{b}$ & $Q_{v}$ & $Q_{a}$ & $Q_{c}$ & $Q_{e}$ \\
\hline 150 & 140 & 102 & 420 & 180 & 240 \\
\hline
\end{tabular}

winter season, and Fig. 5 shows the distribution of $Q_{a}$ which he obtained. The average value of $Q_{a}$ given here is about $420 \mathrm{cal} / \mathrm{cm}^{2} /$ day during winter, and is about the half of the amount of energy exchange obtained in the foregoing sections. As for the exchange of sensible heat, the discrepancy is more remarkable. The error of our estimation caused by the geostrophic approximation for the wind over the Japan Sea is not sufficient to explain this large discrepancy. The most important cause for this descrepancy seems to be the neglection of the seasonal variation of $K$ value in Miyazaki's estimation. During winter, the air on the Japan Sea is extremely unstable, therefore it is natural that the coefficient $K$ is much larger than its annual average. In order to consider this effect reasonably, we treated the energy budget during winter instead of during year. In this 
case the computation of the change of internal energy i.e.,

$$
\begin{aligned}
& \int^{\text {Winter }}\left\{\int_{b m}^{\text {surf. }}\left(\int^{J \cdot S .} d S\right) d z\right\} d t \\
& =C \rho \int_{b m}^{\text {Surf. }}\left\{\int^{J . S .}\left(T^{28} F^{e} b \cdot-T^{1} D^{e} \cdot\right) d S\right\} d z
\end{aligned}
$$

becomes necessary. Where $C$ and $\rho$ are the specific heat and the density of sea water respectively, and $b_{m}$ is the depth of the sea. In Fig. 6, one example of the maps showing

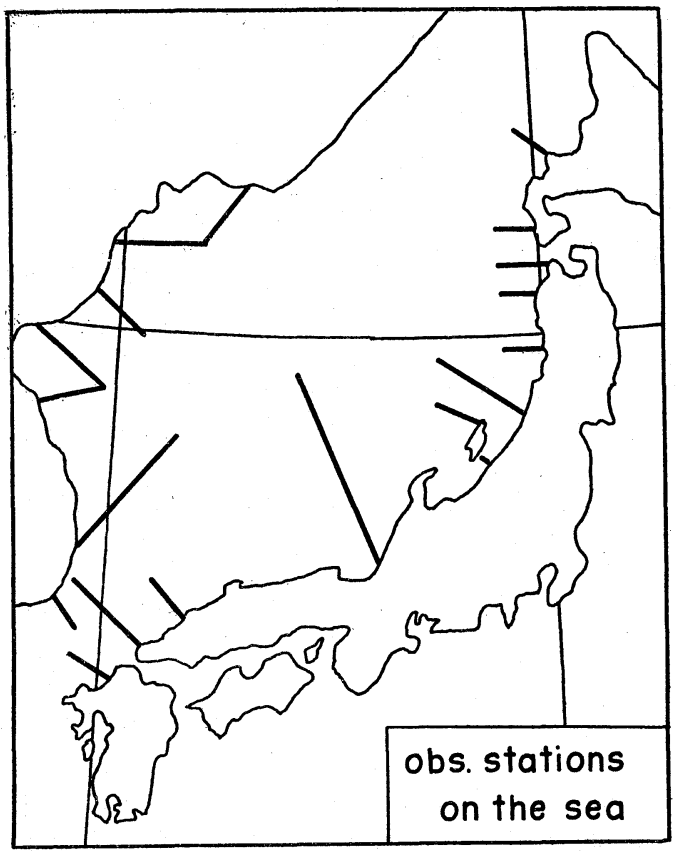

Fig. 6. Map showing the path of the observation ships.

the temperature observations on the Japan Sea is shown. By using the data published by Japan Fishing Research Laboratory, the mean vertical distribution of the amount of temperature change during winter shown in Fig. 7 was obtained $\left(Q_{d}=-768 \mathrm{cal} / \mathrm{cm}^{2} /\right.$ day $)$. As the results, the mean annual value of energy exchange during winter for these 5 years is about $880 \mathrm{cal} / \mathrm{cm}^{2} /$ day which is nearly the same with the value obtained from the energy budget of the atmosphere in the foregoing sections $\left(895 \mathrm{cal} / \mathrm{cm}^{2} /\right.$ day). This estimation was made for the period from 1935 to 1940 when the observations of temperature of sea water at the coast of Korea were abundant, and on

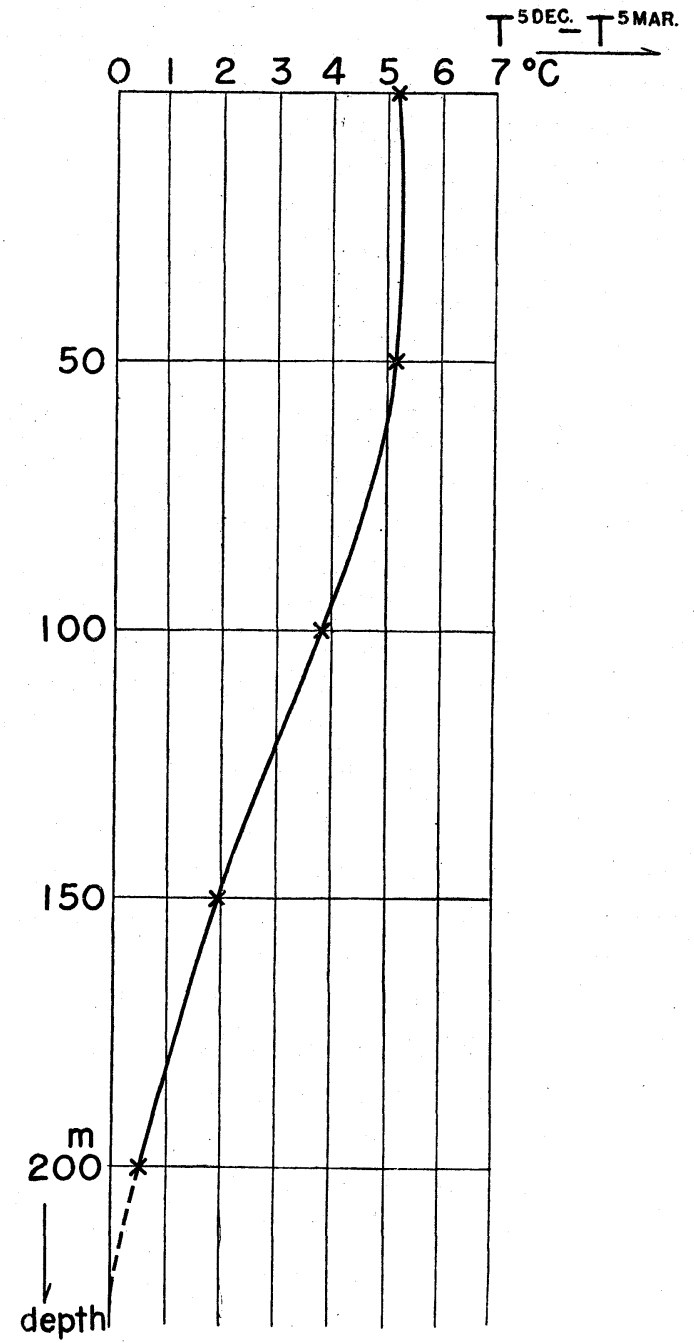

Fig. 7. Vertical distribution of mean annual temperature change during winter in the Japan Sea (1935-1940).

the other hand, our study of airmass modification over the sea was made during the winter from December 1954 to February 1955. Therefore, it is not exact to compare these two results directly. However, at least it might be possible to say that the value of $K$ during winter seems to be considerably larger than its annual average. Accordingly the total energy exchange during winter obtained by Miyazaki (13) and Jacobs (10) may be considerably smaller than the actual value for such a typical unstable situation.

\section{Bowen's ratio}

If we assume that the eddy diffusivity of 


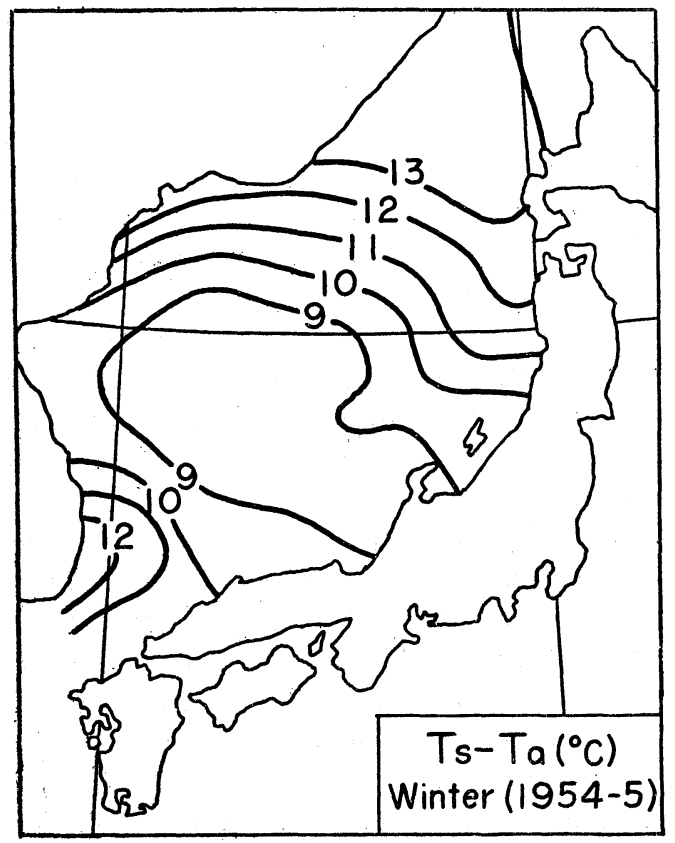

Fig. 8a. Distribution of air-sea temperature difference during winter over the Japan Sea (Dec. 1954-Feb. 1955).

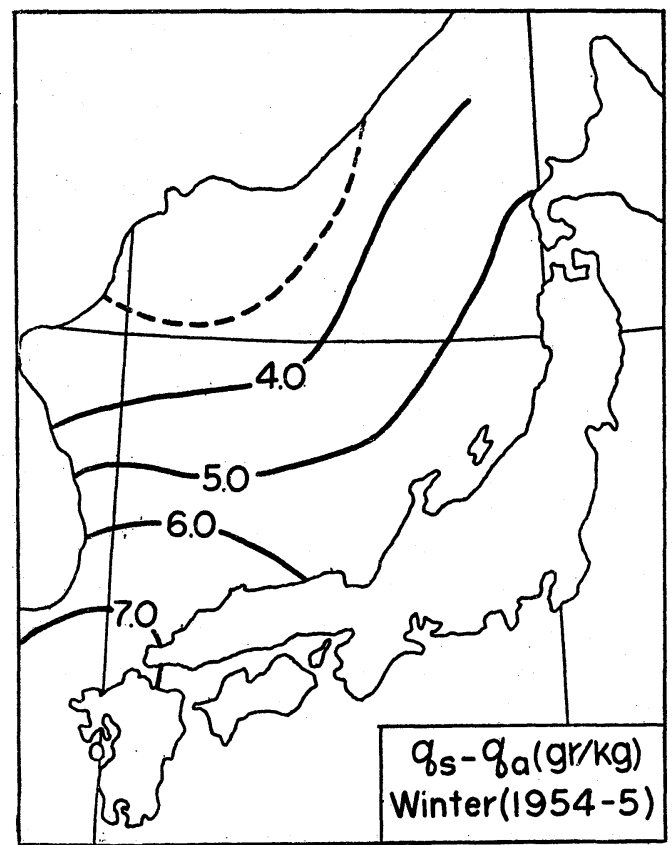

Fig. 8b. Distribution of the mean difference between the saturated mixing ratio of water vapor of sea water and the mixing ratio at the ship deck level during winter over the Japan Sea (Dec. 1954-Feb, 1955).

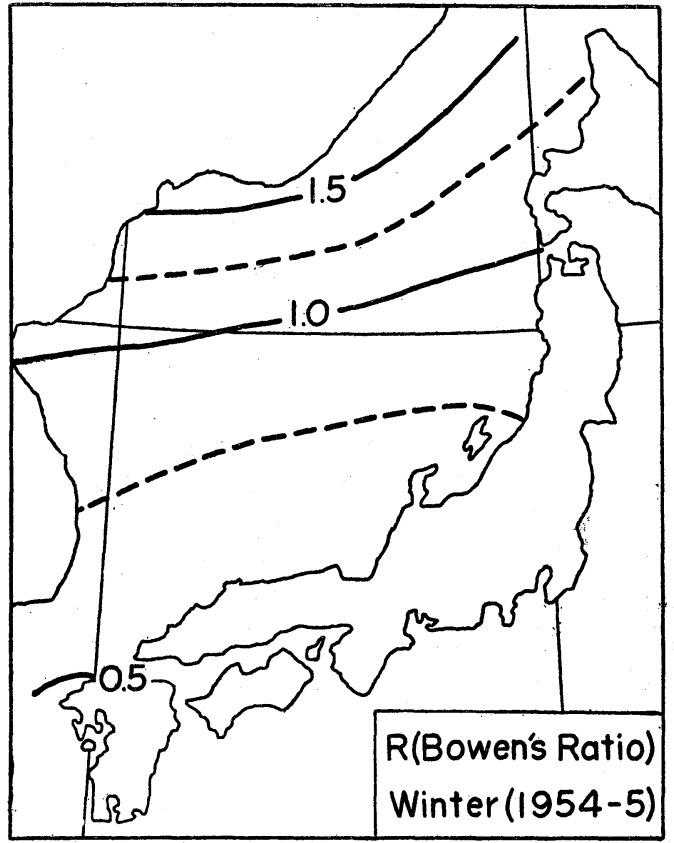

Fig. 8c. Distribution of mean Bowen's Ratio during winter over the Japan Sea (Dec. 1954-Feb. 1955).

water vapor is equal to the eddy conductivity of heat, the ratio $R$ of that loss by conduction to that by evaporation is given by the following formula (Refer equation (6) and (7)).

$$
R=\frac{C_{p}}{L} \frac{T_{s}-T_{a}}{q_{s}-q_{s}}
$$

This ratio is usually called "Bowen's Ratio" (6). In Figs. 8a, 8b and 8c, the mean distributions of $T_{s}-T_{a}, q_{s}-q_{a}$ and this ratio $R$ over the Japan Sea during winter are shown. Like the case of typical outburst period given in the preceding paper, the mean value is about unity. In this section, we shall compare this ratio with the ratio of sensible heat to the latent heat added to the air which is obtained in the foregoing section by use of upper air observations. In Table 3, the ratios for the outburst period at the end of December 1954 and for January and February 1955 are given. From the table we notice that the $Q_{c} / Q_{e}$ is significantly larger than the Bowen's ratio obtained from equation (12) for both periods. According to our rough estimation made in Sec. 2, the underestimation of the amount of evaporation due to the neglection of liquid water content in the cloud is not sufficient to cover this 
Table 3. The ratio at which sensible heat and latent energy are transported from the sea to the atmosphere.

\begin{tabular}{l|c|c}
\hline & Jan. Feb. '55 & Outburst \\
\hline$Q_{c}$ (cal/cm²/day) & 555 & 1030 \\
$Q_{e}\left(\mathrm{cal} / \mathrm{cm}^{2} /\right.$ day $)$ & 328 & 450 \\
$Q_{c} / Q_{e}$ & 1.7 & 2.3 \\
Mean Bowen's Ratio & 1.0 & 1.0 \\
$T_{s}-T_{a}\left({ }^{\circ} \mathrm{C}\right)$ & 10.0 & 12.6
\end{tabular}

discrepancy especially for the typical outburst period. This may be due not to the error of the estimation but to the mechanism of energy transport itself. As is discussed in the preceding paper (12), this results suggest that, in the remarkably unstable situation, the mechanism of heat transfer is not always similar to that of water vapor transport i.e., intense convection may prevail even in the lowest layer of the atmosphere. This is suggested by the tendency that the larger the air-sea temperature difference the larger the $Q_{c} / Q_{e}$ ratio is. As the fractuation of the distribution of temperature is not always similar to that of water vapor, it is not unnatural that the sensible heat is transported more effectively than the latent heat due to the forced convection in the typical unstable situation.

\section{Conclusion and future works}

The results obtained from the estimation in the foregoing section is to be summarized as follows.

1.* The amount of energy exchange of sensible heat between the sea and the atmosphere during January and February 1955 is as much as $555 \mathrm{cal} / \mathrm{cm}^{2} /$ day though it is considerably smaller than that during the typical outburst period at end of December $1954\left(1030 \mathrm{cal} / \mathrm{cm}^{2} /\right.$ day $)$.

$2{ }^{*}$ The mean amount of evaporation during winter is about $5.6 \mathrm{~mm} /$ day which corresponds to the energy exchange of about $340 \mathrm{cal} / \mathrm{cm}^{2} /$ day.

3. From the above results, the mean total amount of energy exchange between the sea and the atmosphere during winter is about $895 \mathrm{cal} / \mathrm{cm}^{2} /$ day. On the other hand, using the revised Miyazaki's method of estimation,

* As for the magnitude of error contained in these estimations, refer the latter half of section 2 . we obtained the mean energy exchange of about $880 \mathrm{cal} / \mathrm{cm}^{2} /$ day during winter from the balance requirement of energy in the sea water. In short, the amount of total energy estimated from the energy budget in the sea water and that estimated from the energy budget of the atmosphere coincide considerably well with each other.

4. The coefficient of energy transport $K$ (refer equation (6) and (7)) during winter seems to be considerably larger than its annual average probably due to the instability during the season.

5. During winter, it might be said that more sensible heat is transported than latent heat over the Japan Sea and this tendency is especially remarkable during the period of the outburst of cold polar continental air when the air-sea temperature difference is very large. The Bowen's ratio, which is computed from the assumption that the heat and water vapor are transported by the same mechanism and gives us the expected ratio at which sensible and latent energy are transported, is nearly equal to unity for both periods. This discrepancy suggests the existence of strong forced convection besides turbulent mixing.

6. The net cooling due to radiation and the heating due to condensation is relatively small in the energy budget of the atmosphere over the Japan Sea.

\section{Acknowledgement:}

The author would like to express his hearty thanks to Prof. S. Syōno and Prof. K. Isono for their guidance and encouragement throughout the course of this study and to Dr. Ogura, Mr. Miyakoda and Mr. Komabayasi, Division of Meteorology, for their helpful discussions and suggestions and also to $\mathrm{Mr}$. Tsuchiya, Division of Oceanography of the same institute who kindly gave the author the effective information about the Japan Sea.

\section{References}

1. Aldrich L. B. (1919): The reflecting power of cloud. Smithon. misc. coll. 69, 10.

2. Angstrom A. (1922): Note on the relation between the time of sunshine and cloudiness in Stockholm, 1908-1920. Arkiv. för Mathematik, Astronom. och Fisik, Bd. 17, no. 15, Stockholm. 
3. Kimbal H. (1928): Amount of solar radiation that reaches the surface of the earth on the land and on the sea. Mo. Wea. Rev., 56, pp. 383-389.

4. Asklöff, S. (1920): Über den Zusammenhang zwischen der nächtilichen Wärmeausstrahlung, der Bewölkung und der Wolkenart. Geogr. Ann. Heft, 3, 7 pp.

5. Benton, G. S. and M. A. Estoque (1954): Water Vapor transfer over the North American continent. J. Meteor. 11, pp. 426-476.

6. Bowen, I. S. (1926): The ratio of heat losses by conduction and by evaporation from any water surface. Phys. Rev. 27, pp. 462-476.

7. Brunt, Physical and Dynamical Meteorology, Cambridge University press.

8. Hewson, E. W. (1943): The reflection, absorption and transmission of solar radiation by fog and cloud. Quart. J. Roy. Meter. Soc. 69, pp. 47-62.

9. Hutchings, J. W. (1957): Water-vapor flux and flux-divergence over southern England: summer 1954. Quart. J. Roy. Meteor. Soc. 83, pp. 30-48.

10. Jacobs, C. W. (1951): The energy exchange between sea and atmosphere and some of its consequences. Bull. Scrips Inst. Ocean. Univ. Cal. 6, pp. 27-122.

11. Kurooka, H. (1957): Modification of Siberian airmass caused by flowing out over the open sea surface of northern Japan. Journ. Met. Soc. Japan, Ser. II, 35, pp. 52-59.

12. Manabe, S. (1957): On the modification of airmass over the Japan Sea when the outburst of cold air predominates. Journ. Met. Soc. Japan, Ser. II, 35, pp. 311-325.

13. Miyazaki, M. (1949): The incoming and out- going heat at the sea surface along the Tsushima warm current. Ocean. Mag. Tokyo, 1, pp. 103-111.

14. Mosby, H. (1936): Verdunstung und Strahlung auf dem Meere. Ann. der Hydrg. u. Marit. Meteor. 54, pp. 281-286.

15. Montgomery, R. B. (1940): Observation of vertical humidity above the ocean surface and and their relation to evaporation. Papers in Physical Ocean. and Meteor. Mass. Inst. of Technol. and Woods Hole Ocean. Inst. 7 , No. $3,30 \mathrm{pp}$.

16. Neiberger, M. (1949): Reflection, absorption and transmission of solar radiation by stratus cloud. J. Meteor. 6, pp. 98-104.

17. Schmidt, W. (1915): Strahlung und Verdunstung an freien Wasser flüchen. Ann. der Hydrogr. u. Marit. Meteor. Heft. 3 u. 4, No. 43, pp. 111-124.

18. Takahashi, K. (1940): On the modification of airmass travelling over the Japan Sea (in Japanese). J. Meteor. Soc. Japan 18, pp. 77-80.

19. Warner, J. (1955): The water content of cumuliform cloud. Tellus 7, 4, pp. 449-457.

20. Wexler, H. (1944): Determination of normal region of heating and cooling in the atmosphere by means of meteorological data. J. Meteor. 1, pp. 23-28.

21. Winston, J. (1955): Physical aspect of rapid cyclogenesis in the Gulf of Alaska. Tellus, 7, pp. 481-500.

22. Yamamoto, G. (1952): On the radiation chart. Sci. Rep. Tohoku Univ. Ser. V, Geophys. 4, pp. 9-23.

23. Yamamoto, G. and G. Onishi, (1952): Absorption of solar radiation by water vapor in the atmosphere. J. Meteor. 9, p. 415.

\section{冬の日本海と大気との間のエネルギー交換について}

先ず毎日のデータを使つて, 冬の日本海から大気に供給される熱量及び 水蒸気量を大気の熱収支から求めた。前 の論文 (12) で日本海に寒気の吹き出しが卓越するときの変質を議論したが，ここでは同じ計算を冬全体について 行つた結果を述べる。従つて, エントロピー及び氷蒸気の流入量流出量の計算, 放射冷却及び凝結の潜熱の解放量 等の見積り法の詳細は前の論文 (12) を参照されたい。前にも述べた様に、周辺を密な観測網で团まれた日本海は この種の研究にはもつてこいの場所であろう。得られた結果を簡単に述べる。

1955 年 1 月及び 2 月について顕熱供給量を得たが平均約 $555 \mathrm{cal} / \mathrm{cm}^{2} / \mathrm{day}$ で相当大きな值である。これは放射 によつて逃げる熱量或いは凝結の潜熱発生量の数倍になる。尤も前に求めた典型的な吹き出しの時（1554 年 12 月 下旬）の顕熱供給量 $1030 \mathrm{cal} / \mathrm{cm}^{2} / \mathrm{day}$ に比べればずつと小さい。この事は又気象状態に応じて供給量がかなり大 きく変動する事を暗示している。 
一方同じ冬について平均蒸発量を計算した。即ち約 $5.6 \mathrm{~mm} / \mathrm{day}$ でこれを熱量に換算すると約 $340 \mathrm{cal} / \mathrm{cm}^{2} / \mathrm{day}$ となる。ここで興味ある事は, 顕熱供給量が潜熱供給量を遙かに上迴つているという事である。この傾向が水温と 気温との差の更に大きい典型的吹き出しの時一層顕ちよになるという事は前の論文 (12) を参照すればわかる。と ころがこの期間の日本海での平均ボーエン比を計算して見たが,吹き出しのときと同様ほぼ 1 に近い。この違いは， 冬の日本海の様な不安定なところでは，恐らく対流が非常に盛んで熱と水蒸気とが必ずしも古典乱流論で仮定した ように同じメカニズムで供給されていない事を暗示している様に思われる。

次に上の計算結果を確かめるため, 冬の日本海水の熱収支の計算を行つた。既に W. Jacobs 氏 (10) 及び宮崎氏 (13)は，海の一年間の熱収支をるとにしてェネルギー交換量の経験式を出したが，ここでは冬期について収支計算 を行つた。従つて冬期の水温变化のデーターを用いたが，この点が彼等の場合と違う点である。その結果大気の熱 収支から得られた全エネルギー供給量に近い值を得る事がでさた（約 $880 \mathrm{cal} / \mathrm{cm}^{2}$, day）。ここで気付いたのは，エ ネルギー供給係数が安定度によつてかなり違うらしく, 従つて Jacobs 氏或は宮崎氏が年平均のエネルギー供給係 数を使つて求めた值は, 冬の日本海の様な不安定な場所では, かなり実際より小さいらしいという事である。 